\title{
DEUTERIUM TRAPPING AND SPUTTERING OF TUNGSTEN COATINGS EXPOSED TO LOW-ENERGY DEUTERIUM PLASMA
}

\author{
G.D. Tolstolutskaya ${ }^{1}$, A.S. Kuprin ${ }^{1}$, A.V. Nikitin ${ }^{1}$, I.E. Kopanets ${ }^{1}$, V.N. Voyevodin ${ }^{1,2}$, \\ I.V. Kolodiy, ${ }^{1}$, R.L. Vasilenko ${ }^{I}$, A.V. Ilchenko ${ }^{1}$ \\ ${ }^{1}$ National Science Center "Kharkov Institute of Physics and Technology", Kharkiv, Ukraine; \\ ${ }^{2}$ V.N. Karazin Kharkiv National University, Kharkiv, Ukraine
}

\begin{abstract}
Processes of sputtering, surface modification and deuterium retention of tungsten coatings were studied under the influence of low-energy $(500 \mathrm{eV})$ deuterium plasma with fluence $\left(2 \cdot 10^{24} \mathrm{D}^{+} / \mathrm{m}^{2}\right)$ at room temperature. The method of cathodic arc evaporation was used to deposit W and WN-coatings on stainless steel. Results of erosion studies indicated that the sputtering yields for coatings $\mathrm{WN}$ and $\mathrm{W}$ are $3.1 \cdot 10^{-3}$ and $4.8 \cdot 10^{-3}$ at./ion, respectively, and at least two times larger compared to bulk $\mathrm{W}$ but almost an order of magnitude smaller compared to ferritic martensitic steels. The total D retentions of W coatings were on the order of $5 \cdot 10^{19} \mathrm{D} / \mathrm{m}^{2}$ and around one orders of magnitude lower than that of WN.
\end{abstract}

PACS: 52.40Hf, 28.52Fa, 68.49Sf, 79.20Rf

\section{INTRODUCTION}

Tungsten (W) is a promising plasma-facing material (PFMs) for ITER and future fusion reactors due to its favorable thermo-mechanical properties, low hydrogen permeability, low sputtering erosion yield, high thermal conductivity and no chemical reaction with hydrogen [1]. However, it is currently believed that the manufacture of the first wall of a fusion reactor entirely from tungsten is not economically viable because of high cost implications to the project, difficulties in machining due to its hardness and brittleness of $\mathrm{W}$ and bulkiness resulting in large structural weight. Tungsten coatings on a stainless-steel substrate can be considered as a good solution in terms of economic and the protection of structural material from interaction with the plasma [2].

To assess the possibility to use the $\mathrm{W}$ coatings as PFMs, there is a need to examine a behavior of these materials under plasma exposure. Sputtering of PFMs due to interaction with energetic ions (particularly hydrogen isotopes) is an essential issue in magnetically confined fusion devices because it is directly related to impurity generation as well as to the lifetime of plasmafacing components [3].

For divertor radiative cooling by impurity seeding, different noble gases like $\mathrm{Ne}$ and $\mathrm{Ar}$ have been tested, but the best results so far have been obtained with $\mathrm{N}_{2}$ seeding [4, 5]. An overall improvement of the plasma confinement was detected thanks to a strongly reduced power load to divertor surfaces and the total suppression of $\mathrm{W}$ influx into the plasma [6]. One of the reasons of these effects has been development of tungsten nitrides films at the surface of the $\mathrm{W}$ tiles reducing the $\mathrm{W}$ sputtering. This decrease is related to the accumulation of nitrogen at the tungsten surface, thus reducing the possibility of a tungsten atom being sputtered out, combined with the similar, large bonding energy of $\mathrm{W}-\mathrm{W}$ and $\mathrm{W}-\mathrm{N}(\sim 8.6 \mathrm{eV})$. However, before using tungsten nitride coatings in tokamaks, it must be studied how the processes of hydrogen isotopes retention and the formation of blisters proceed in them, due to the possible long-term trapping of tritium, which could lead to an important safety issue; finding out if the tungsten nitrides will survive the divertor tokamak conditions (temperature and particle loads). In addition, it is need to determine the sputtering at particle loads similar to the expected in ITER.

The goal of this work is to experimentally determine the sputtering yields, surface morphology changes and deuterium retention of $\mathrm{W}$ and $\mathrm{WN}$ coatings that are deposited by the cathodic arc evaporation and exposed to low-energy deuterium plasma.

\section{MATERIAL AND METHODS}

A set of tungsten coatings was formed using unfiltered cathodic arc evaporation in a "Bulat-6" system equipped with a W $(99.9 \%)$ cathode of $60 \mathrm{~mm}$ diameter [7]. The substrate-cathode distance was about $250 \mathrm{~mm}$. A vacuum-arc plasma source with magnetic stabilization of a cathode spot was used. The arc current was $140 \mathrm{~A}$. The chamber was evacuated to a pressure of $2 \cdot 10^{-3} \mathrm{~Pa}$. Coatings were deposited on the substrates $(10 \times 20 \times 1.5 \mathrm{~mm})$ of stainless steel $18 \mathrm{Cr} 10 \mathrm{NiTi}$ at a negative bias potential of $-50 \mathrm{~V}$ without rotation. The $\mathrm{W}$ coatings were deposited in vacuum $\sim(3 \ldots 4) \cdot 10^{-3} \mathrm{~Pa}$ and WN coatings under nitrogen pressure $\sim 2 \mathrm{~Pa}$. The substrate temperature during deposition did not exceed $500{ }^{\circ} \mathrm{C}$. The coating deposition rate was $\sim 6 \mu \mathrm{m} / \mathrm{h}$.

The $\mathrm{W}$ and $\mathrm{WN}$ coatings have been irradiated with deuterium ions using glow gas-discharge plasma at $1000 \mathrm{~V}$. The design and principle of operation of the gaseous plasma source used for irradiation of the samples is described in detail in [8]. The specimen temperature was measured by the thermocouple and was $(30 \pm 2.5){ }^{\circ} \mathrm{C}$ during irradiation. The maximum irradiation fluence was $4 \cdot 10^{24} \mathrm{~m}^{-2}$. The experimental ion flux and fluence were calculated from the measured ion currents and beam spot areas.

The erosion yield was primarily evaluated by a weight-loss technique. Before and after plasma exposure, the weight of each target was measured by a microbalance system, and the erosion rate was then calculated from the weight loss and the total deuterium fluence.

The implanted deuterium depth distribution was measured by means of the $\mathrm{D}\left({ }^{3} \mathrm{He}, \mathrm{p}\right){ }^{4} \mathrm{He}$ nuclear reaction (NRA). The measurements were performed at room temperature using back scattering geometry. Deuterium 
depth profiles were extracted from the obtained data using "Helen" software [9].

XRD analysis was performed by DRON-4-07 diffractometer using $\mathrm{Cu}-\mathrm{K} \alpha$ filtered radiation. Residual macrostress analysis of the samples was carried out by the $\sin 2 \psi$-method. Lattice parameters in the unstrained state $\mathrm{a}_{0}$ were calculated from $\sin ^{2} \psi$-plots.

Investigations of surface microstructure before and after irradiation were performed using scanning electron microscope JEOL JSM-7001F. Chemical composition of the coatings was determined by energy dispersive X-ray spectroscopy - EDS.

\section{RESULTS AND DISCUSSION}

Fig. 1 shows a view of cross-section of the $\mathrm{W}$ and WN coatings deposited by CAE. The surface and interface between the coating and substrate are indicated by the white horizontal line. The coating thickness is about $5 \mu \mathrm{m}$. Within the coating we can see the grains with dimensions in the $\mu \mathrm{m}$ range and the absence of a pronounced columnar structure.
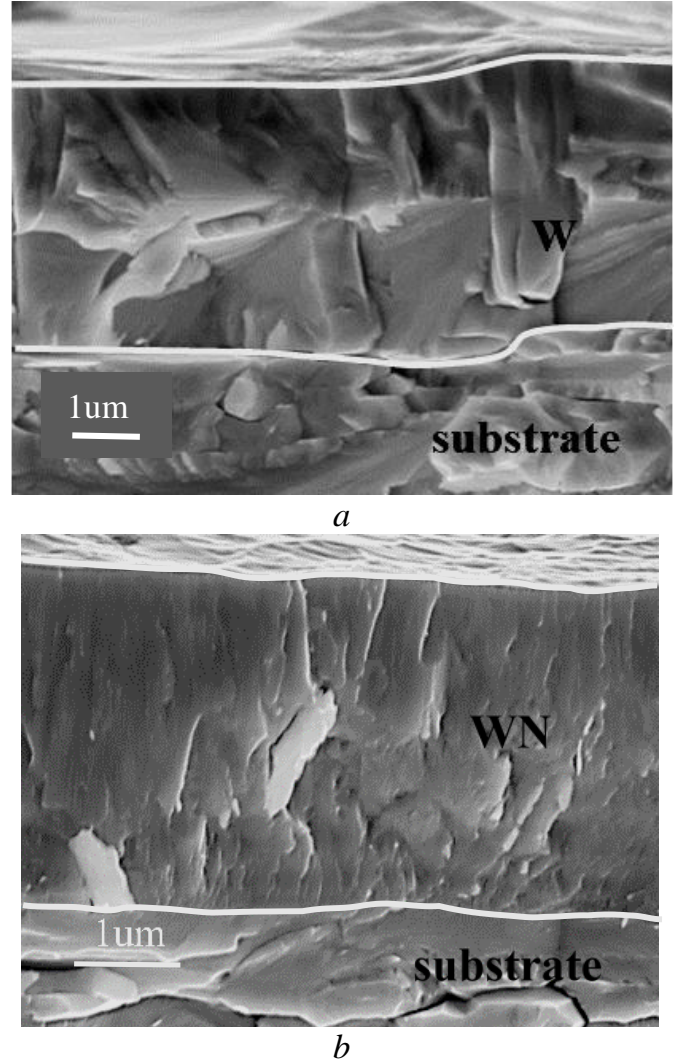

Fig. 1. Cross-section SEM images of $W(a)$ and $W N(b)$ coatings

The structure of $\mathrm{W}$ and $\mathrm{WN}$-coating is dense and without pores (see Fig. 1). The absence of columnar structure into those coatings may be explained by sufficiently high energy of deposited tungsten ions and by the high degree of plasma ionization relatively to the flow of evaporated material which is characteristic of cathodic arc evaporation method [10]. WN-coating has a less refined microstructure with columnar structure elements (see Fig. 1,b) and near stoichiomertic concentration of $\mathrm{N} \sim 50$ at.\% according to EDS analysis.

$\mathrm{X}$-ray diffraction patterns of the $\mathrm{W}$ and $\mathrm{WN}$ coatings are shown in Fig. 2. Diffraction pattern of W corresponds to the single-phase $\alpha$-modification of tungsten (see Fig. 2,a) with lattice parameter $a=(3.1730 \pm 3) \cdot 10^{-4} \AA$. Lattice parameter in unstrained state $a_{0}=(3.1668 \pm 3) \cdot 10^{-4} \AA$ is large than literature data ( $a=3.1648 \AA$ ) due to presence of impurities and/or interstitial atoms. Only one phase was revealed in the $\mathrm{WN}$ coating - hexagonal tungsten nitride $\mathrm{WN}-\delta$ (hexagonal system, space group No. 187, structural type WC) (see Fig. 2,b).

The sharp peaks indicate a high crystallinity of the $\mathrm{W}$ and WN coatings. Compared with the standard card, the coatings have obvious preferred orientation (110) shown in Fig. 2. In addition, an analysis of the substructural characteristics (the crystallite size and the level of microstrains $\varepsilon$ ) was carried out according to the integral width of the diffraction lines (Williamson-Hall method). The parameters determined by diffractometric studies of samples from $\mathrm{W}$ and $\mathrm{WN}$, namely, the lattice period, macrostresses, crystallite size and microstrains are given in Table 1.
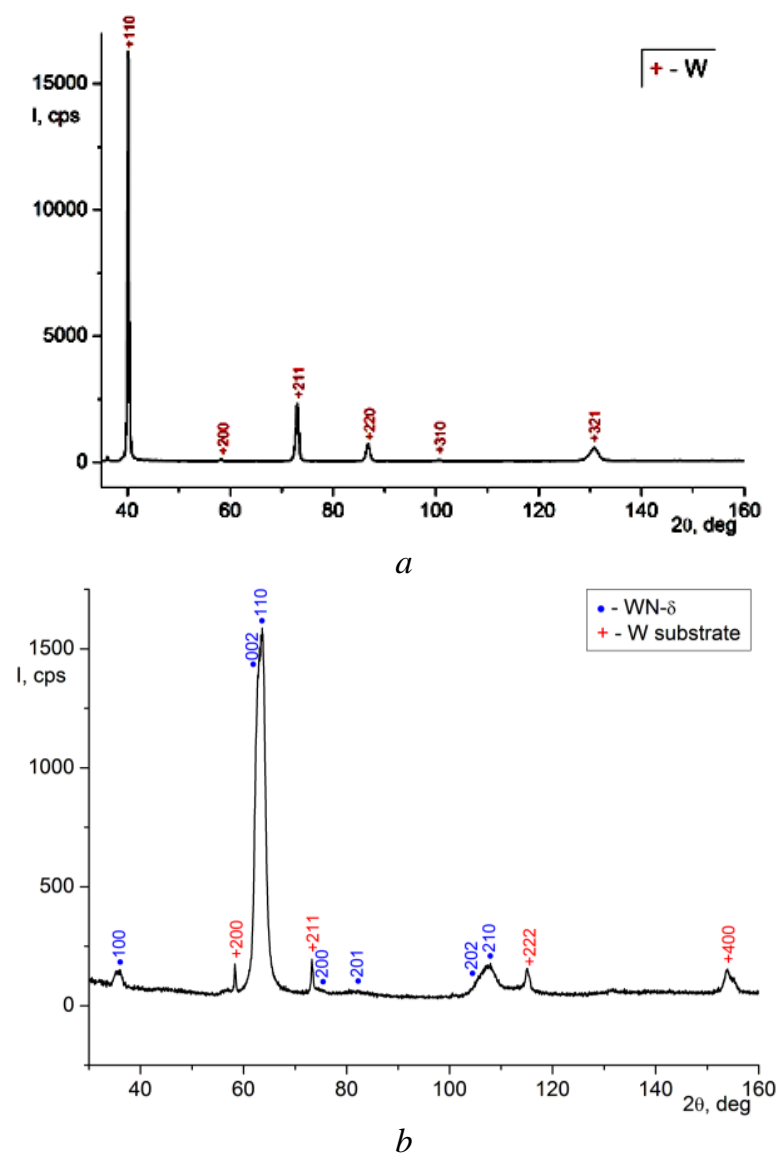

Fig. 2. X-ray diffraction patterns of $W(a)$ and $W N(b)$ coatings

Table 1

Structural and substructural parameters of $\mathrm{W}$ and $\mathrm{WN}$

\begin{tabular}{|c|c|c|c|c|}
\hline Sample & $\begin{array}{c}\text { Lattice } \\
\text { period, } \\
\AA\end{array}$ & $\begin{array}{c}\text { Macro- } \\
\text { stresses } \sigma_{\varphi} \\
\mathrm{GPa}\end{array}$ & $\begin{array}{c}\text { Crystallite } \\
\text { size, } \\
\mathrm{nm}\end{array}$ & $\begin{array}{c}\text { Micro- } \\
\text { strains } \\
\varepsilon, \times 10^{-3}\end{array}$ \\
\hline $\mathrm{W}$ & $a=3.1730$ & -1.63 & 46.9 & 2.55 \\
\hline $\mathrm{WN}$ & $\begin{array}{c}a=2.922 \\
c=2.964\end{array}$ & - & 29.8 & 7.81 \\
\hline
\end{tabular}

The macrostress analysis of the samples were carried out by the $\sin ^{2} \psi$-method (tilt angles $\psi=-45 ;-30 ; 0 ; 30$; 
$45^{\circ}$, as well as $\varphi=-60 ; 0$, and $\left.+60^{\circ}\right)$. The lattice parameters of both types of coatings are much larger than the literature values, which is most likely due to the presence of compressive stress in the coating.

Fig. 3 shows an SEM image the surface microstructure of the $\mathrm{W}$ and $\mathrm{WN}$ coatings in the initial
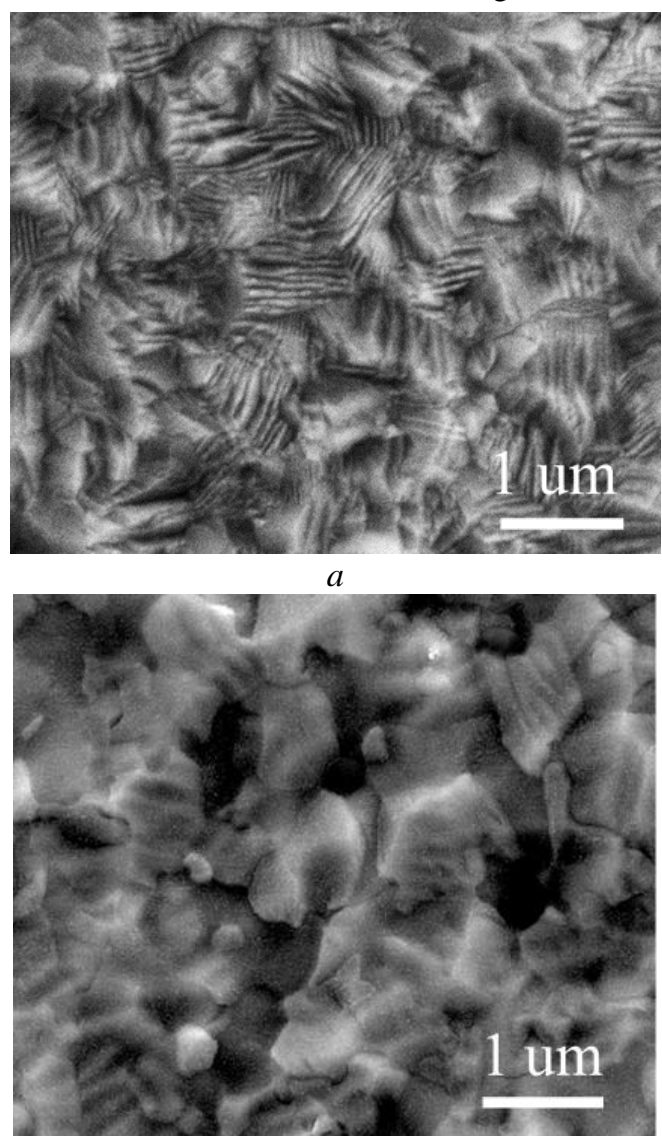

$c$

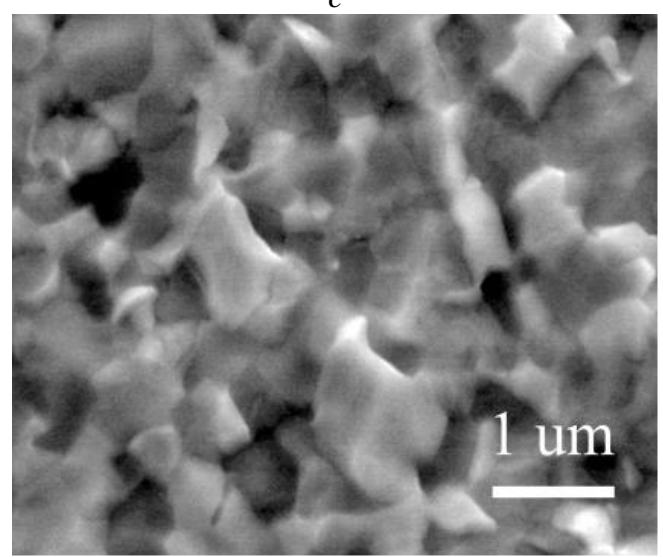

state and after exposed to plasma. As can be seen from Fig. 3 irradiation of tungsten coatings did not lead to the formation of blisters. Only the process of sputtering is observed.
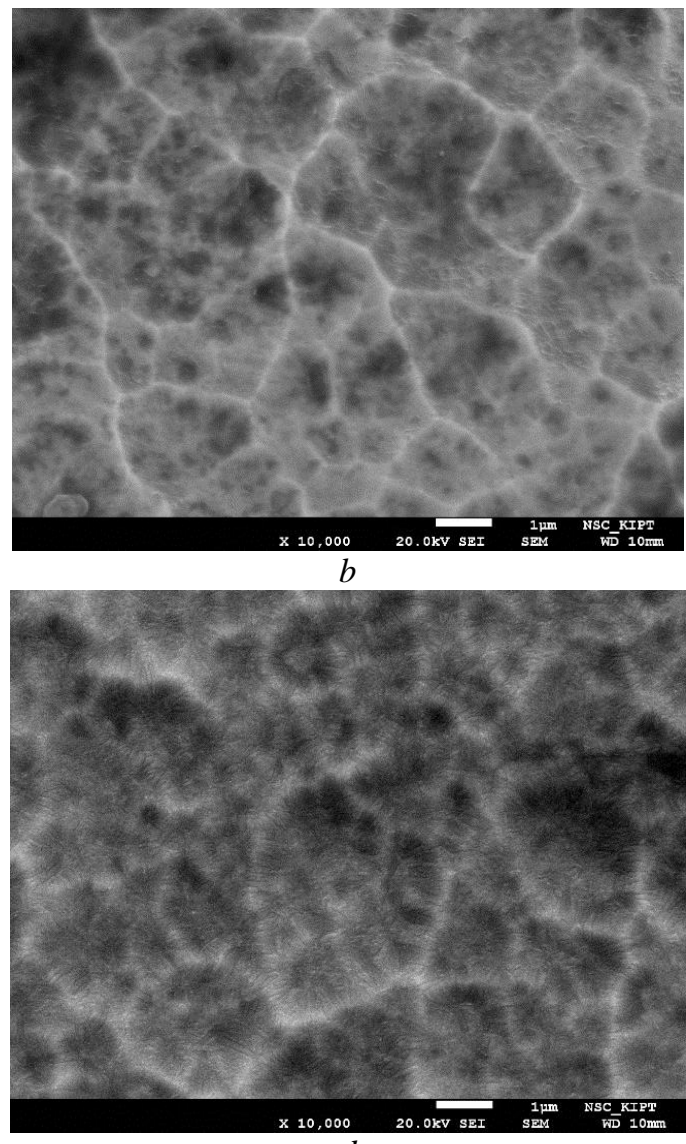

$d$

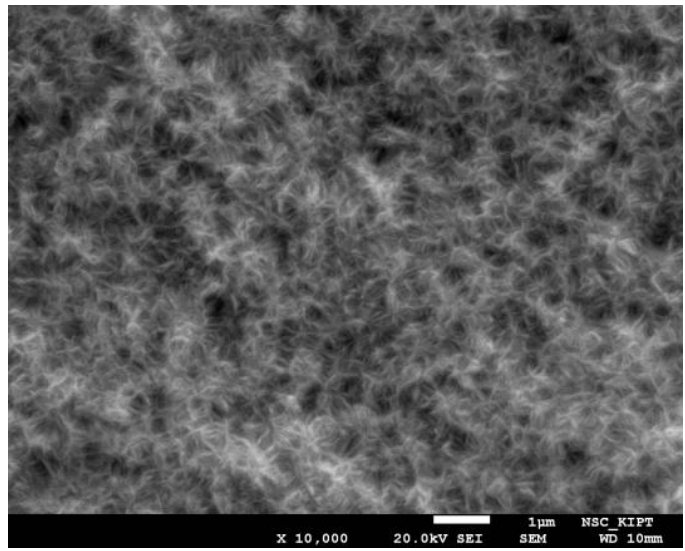

$f$

Fig. 3. SEM images of morphology of $W(a, c, e)$ and $W N(b, d, f)$ coatings in initial state $(a, b)$ and after irradiation at $300 \mathrm{~K}$ with $1 \mathrm{keV} \mathrm{D}_{2}^{+}$to $1 \cdot 10^{24} \mathrm{D}_{2}^{+} / \mathrm{m}^{2}(\mathrm{c}, d)$ and to $2 \cdot 10^{24} \mathrm{ion} / \mathrm{m}^{2}(e, f)$

Initial $\mathrm{W}$ coatings exhibit surfaces of densely packed "nanoridges" or overlapping tiles (see Fig. 3,a). Previously reported in [11] that these "nanoridges" were observed on the $\alpha-\mathrm{W}$ phase film surfaces irrespective of the film thickness. It is shown that many individual grains contain two types of "nanoridge" domains oriented with each other with an angle ranging between 109 and $124^{\circ}$. Each domain has ridges with an average height and period of $(1.5 \pm 0.5)$ and $(7.5 \pm 1.0) \mathrm{nm}$, respectively [12].
It was suggested that an anisotropic surface diffusion mechanism on crystalline $\mathrm{W}$ film is responsible for the formation of such nanostructures. Every atom on the surface lattice structures of the $\alpha-\mathrm{W}\left(\begin{array}{lll}1 & 1 & 0\end{array}\right)$ plane in the topmost layer has four nearest-neighbors and two nextnearest-neighbors located at the distances of $\sqrt{ } 3 \mathrm{a} / 2$ and $a$ in the topmost layer, respectively, where $a$ is the lattice constant of bcc $\alpha-\mathrm{W}\left(\begin{array}{lll}1 & 1 & 0\end{array}\right)$ structure. The anisotropy in diffusion barriers along different directions is large and therefore $\mathrm{W}$ adatom motion on the $\mathrm{W}\left(\begin{array}{lll}1 & 1 & 0\end{array}\right)$ plane 
should differ in different directions. In [13] a detailed study of the self-diffusion of $\mathrm{W}$ on $\mathrm{W}$ lattice by using field ion microscopy have done. It was shown that the surface diffusion not only depends on the plane index but also on the crystallographic directions on a particular plane and can be anisotropic. So, the formation of "nanoridges" oriented in the high mobility $\langle 111\rangle$ directions are a result of the anisotropic surface diffusion of $\mathrm{W}$ particles over the $\alpha-\mathrm{W}\left(\begin{array}{lll}1 & 1 & 0\end{array}\right)$ surface.

The $\delta-\mathrm{WN}$ is not an amorphous phase but perhaps, there is no preferred direction for diffusion of the impinging $\mathrm{W}$ adatoms on the $\delta$-WN coating surface. Thus, no ridge patterns were visible on the $\delta$-WN coating surface (see Fig. 3,b). Instead, the surface topography shows the smooth and fine cellular structure.

The evolution of the surface of $\mathrm{W}$ coating due to the sputtering process after exposure to a deuterium plasma is shown in Fig. 3,c,e. The "nanoridges" preferentially sputtered at a dose $1 \cdot 10^{24} \mathrm{D}_{2}{ }^{+} / \mathrm{m}^{2}$ (see Fig. 3,c) and completely sputtered at a dose $2 \cdot 10^{24} \mathrm{D}_{2}^{+} / \mathrm{m}^{2}$ (see Fig. 3,e). As can be seen on the SEM picture in Fig. 3,e areas towering above surface of microparticles were sputtered also.

The evolution of the surface of $\delta$-WN coating due to exposure to a deuterium plasma as shown in Fig. 3,d,f caused by the sputtering process of cellular structure at an intermediate dose of irradiation up to obtaining needle like morphology at a dose $2 \cdot 10^{24} \mathrm{D}_{2}{ }^{+} / \mathrm{m}^{2}$.

Table 2 shows the results for the sputtering yields (Y) of $\mathrm{W}$ and $\mathrm{WN}$ coatings in comparison with published data of sputtering yields of bulk tungsten [14] and reduced-activation ferritic martensitic (RAFM) steels as promising candidates for PFMs in future fusion power plants [15]. The sputtering yield was determined from the weight loss and the total deuterium fluence for accordingly $500 \mathrm{eV} / \mathrm{D}$ as dominant impinging energy. Data for comparison were taken at the same energy of deuterium ions.

Table 2

Sputtering yields of coatings and RAFM steels for deuterium $(500 \mathrm{eV})$

\begin{tabular}{|c|c|c|c|c|}
\hline Material & $\mathrm{W}$ & $\mathrm{WN}$ & $\mathrm{W}_{\text {bulk }}[14]$ & F-M SS [15] \\
\hline $\mathrm{Y}$, at./ion & $4.8 \cdot 10^{-3}$ & $3.1 \cdot 10^{-3}$ & $2.2 \cdot 10^{-3}$ & $3 \cdot 10^{-2}$ \\
\hline
\end{tabular}

As seen in Table 2, values of the experimentally measured sputtering yield of the tungsten coatings exposed to the D plasma are two times larger compared to bulk W but almost an order of magnitude smaller compared to ferritic martensitic (RAFM) steels. It should be noted that the WN coatings have the sputtering coefficient which is almost one and a half times smaller in comparison with $\mathrm{W}$ coatings. In Ref. [16] it has been detected that $\mathrm{W}_{2} \mathrm{~N}$ films presents a nitrogen preferential sputtering by deuterium, probably enhanced by chemical reactions towards ammonia production.

As an important issue for ITER and DEMO, fuel retention and diffusion in first-wall materials presents a safety (tritium amount in ITER < $700 \mathrm{~g} \mathrm{[17])} \mathrm{and} \mathrm{cost}$ concern. In general, hydrogen retention in $\mathrm{W}$ is low
$[18,19]$ but diffusion at elevated temperatures $(>400 \mathrm{~K})$ is relatively fast [18].

In the present work the retention and depth distribution of $\mathrm{D}$ in coatings after plasma exposure were measured by NRA method. Fig. 4 presents the depth distribution profile of deuterium implanted to a dose of $1 \cdot 10^{24} \mathrm{D}_{2}^{+} / \mathrm{m}^{2}$ at $T_{\text {room }}$ in $\mathrm{W}$ coating, and its evolution during aging at $T_{\text {room }}$ for 30 days.

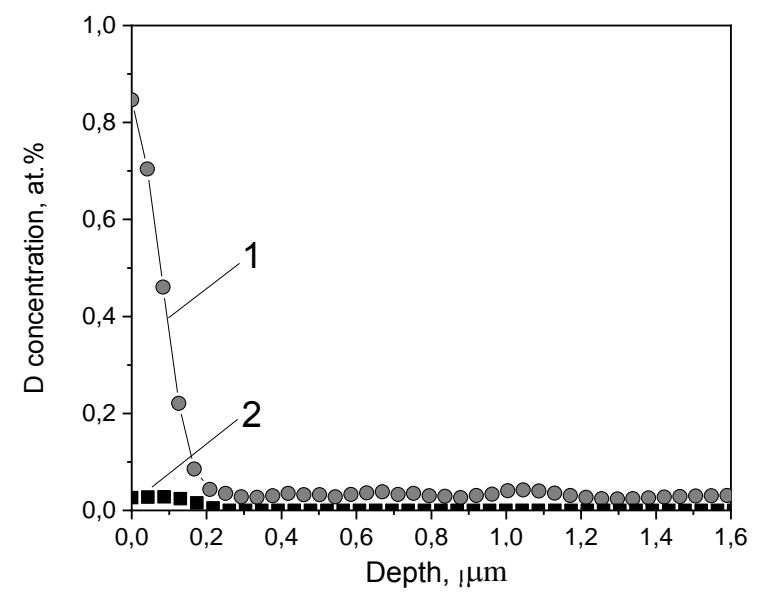

Fig. 4. Depth profiles of $D$ in $W$ coatings with a thickness of $5 \mu \mathrm{m}$ on the steel substrate measured after the D plasma exposure (1) and after 30 days (2)

The calculated normal-incident range of $0.5 \mathrm{keV} \mathrm{D}$ in tungsten is about $7 \mathrm{~nm}$. Immediately after exposure the deuterium depth profile localized at about $0.1 \mu \mathrm{m}$, which is determined by the resolution of the NRA method in the backscattering geometry and a large gradient of deuterium concentration. After exposure at $T_{\text {room }}$ for 30 days deuterium was penetrated into a depth up to $1.6 \mu \mathrm{m}$. A small amount of deuterium is captured at $0.6 \ldots 0.8 \mu \mathrm{m}$ on defects created by an analyzing beam of $\mathrm{He}^{3}$ ions.

NRA depth profiling of D-implanted WN films has indicated that $\mathrm{D}$ is retained only in a thin surface layer $(<0.2 \mu \mathrm{m})$ and even after exposure at $T_{\text {room }}$ for 30 days its depth distribution remains virtually unchanged (Fig. 5). However, its amount is decreased almost 1.5 times, probably due to desorption from the sample [20].

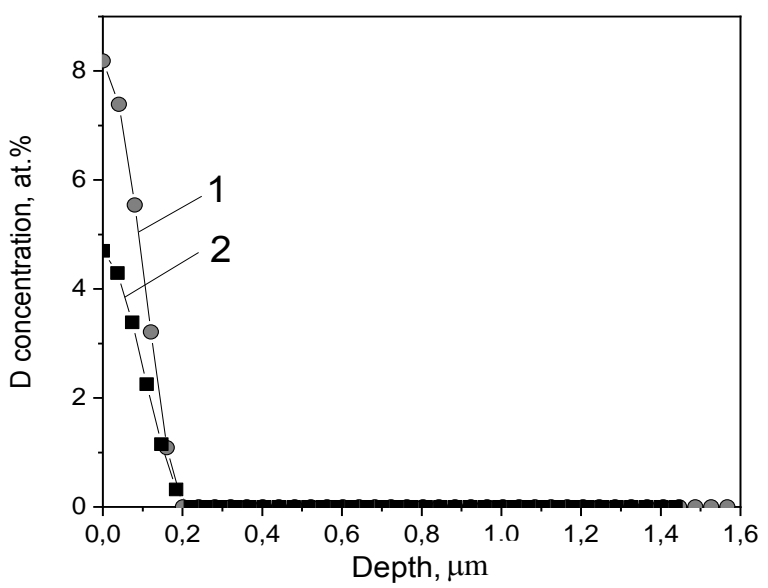

Fig. 5. Depth profiles of $D$ in WN coatings with a thickness of $5 \mu \mathrm{m}$ on the steel substrate measured after the D plasma exposure (1) and after 30 days (2) 
In Ref. [21] it was proposed that hydrogen trapping first occurs predominantly within the implantation zone at impurities, dislocations, vacancies, grain boundaries and other crystal defects. If all the traps in the implanted zone become filled, and the flux of hydrogen is larger than the rate of hydrogen diffusion out of the implantation zone, there will exist a local supersaturation of mobile hydrogen. Additional hydrogen introduced by prolonged irradiation will then diffuse deeper into the sample, filling traps beyond the ion range, expanding the distribution of deuterium.

The first analysis presented by many groups in the PFMC 2013 conference [4] points to an increased D retention at the surface due to a lower $\mathrm{D}_{2}$ recombination rate and/or tungsten nitrides acting as a diffusion barrier for deuterium. The first possibility will cause a larger D retention in the crystalline defects in bulk tungsten, but the second one would greatly decrease that retention if the nitrogen layer is below the ion implantation range.

A set of bulk W samples was implanted with D up to a fluence of $1 \cdot 10^{24} \mathrm{D} \cdot \mathrm{m}^{-2}$ with or without $\mathrm{N}$ preimplantation at 300 and $500 \mathrm{~K}$. The surface modification by blistering as well as the $\mathrm{D}$ depth distribution measured by NRA show that $\mathrm{N}$ preimplantation plays a very different role for $\mathrm{D}$ retention in the following D plasma exposure at the different applied temperatures: At $500 \mathrm{~K}$, the $\mathrm{W}-\mathrm{N}$ layer strongly enhances D retention; while at $300 \mathrm{~K}$ it has no obvious effect [22].

Recent experiments [23] have indicated that a thin $\mathrm{N}$-containing layer present during plasma loading at $500 \mathrm{~K}$ could reduce the loss of D through the surface thus increasing D retention. Furthermore, NRA depth profiling of D-implanted WNx films has indicated that $\mathrm{D}$ is retained only in a thin surface layer. It was hypothesized that $\mathrm{D}$ is retained only in the ion penetration range of the impinging D ions and does not, as in bulk W, diffuse to greater depth.

$\mathrm{D}$ retention in WNx layers deposited on bulk W was studied as a model system for some aspects of plasmasurface interaction in $\mathrm{N}$-seeded discharges in fusion devices with a W first wall. Results show that D is retained in the topmost surface only and does not diffuse into deeper layers of the $\mathrm{WNx}$ film at the temperature of $300 \mathrm{~K}$. This is in contrast to the behavior of pure W films and bulk W samples which clearly show diffusion to larger depth at this temperature [18].

The presented literature data and experimental results obtained in this work indicate that WNx films might be applicable as D diffusion barriers in future fusion applications.

\section{CONCLUSIONS}

Processes of sputtering, surface modification and deuterium retention of $\mathrm{W}$ and $\mathrm{WN}$ coatings deposited on stainless steel by cathodic arc evaporation were studied under the influence of low-energy $(500 \mathrm{eV})$ deuterium plasma with fluence $\left(4 \cdot 10^{24} \mathrm{D}^{+} / \mathrm{m}^{2}\right)$ at room temperature.

Coatings deposited in vacuum have a single crystalline $\alpha-\mathrm{W}$ phase with crystallite size $\sim 46.9 \mathrm{~nm}$ and microstrain $\sim 2.55 \cdot 10^{-3}$. Deposition under a nitrogen pressure of $2 \mathrm{~Pa}$ leads to the formation of $\delta$-WN nitride coatings with crystallite size $\sim 29.8 \mathrm{~nm}$ and microstrain $\sim 7.81 \cdot 10^{-3}$. All deposited coatings having dense microstructure without pores.

Values of the experimentally measured sputtering yield of the tungsten coatings exposed to the D plasma are two times higher compared to bulk $\mathrm{W}$ but almost an order of magnitude smaller compared to PFM - ferritic martensitic steels. The WN coatings have the sputtering coefficient which is almost one and a half times smaller in comparison with $\mathrm{W}$ coatings.

The total $\mathrm{D}$ retentions of $\mathrm{W}$ coatings were on the order of $5 \cdot 10^{19} \mathrm{D} / \mathrm{m}^{2}$ and around one orders of magnitude lower than that of $\mathrm{WN}$, which can be attributed to fast deuterium diffusion in the $\mathrm{W}$ coating within the depth of $1.6 \mu \mathrm{m}$.

\section{ACKNOWLEDGEMENTS}

The work was financially supported by the National Academy of Science of Ukraine (program "Support of the development of main lines of scientific investigations" (KPKVK 6541230)).

\section{REFERENCES}

1. R.A. Pitts, X. Bonnin, F. Escourbiac, et al. Physics basis for the first ITER tungsten divertor // Nuclear Materials and Energy. 2019, v. 20, p. 100696.

2. C. Ruset, E. Grigore, H. Maier, R. Neu, H. Greuner, M. Mayer, and G. Matthews. Development of W coatings for fusion applications // Fusion Eng. Des. 2011, v. 86(9-11), p. $1677-1680$.

3. P. Sigmund. Theory of sputtering. I. Sputtering yields of amorphous and polycrystalline targets // Physical Review. 1969, v. 184, p. 383-345.

4. R. Neu, A. Kallenbach, M. Balden, et al. Overview on plasma operation with a full tungsten wall in ASDEX Upgrade // Journal of Nuclear Materials. 2013, v. 483 , p. S34-S41.

5. L. Gao, W. Jacob, G. Meisl, T. SchwarzSelinger, T. Höschen, U. von Toussaint, and T. Dürbeck. Interaction of deuterium plasma with sputterdeposited tungsten nitride films // Nucl. Fusion. 2016, v. 56, p. 016004 (17 p.).

6. K. Dobes, V. Smejka, T. Schäfer, F. Aumayr. Interaction between seeding gas ions and nitrogen saturated tungsten surfaces // International Journal of Mass Spectrometry. 2014, v. 365-366, p. 64-67.

7. A.S. Kuprin, S.A. Leonov, V.D. Ovcharenko, E.N. Reshetnyak, V.A. Belous, R.L. Vasilenko, G.N. Tolmachova, V.I. Kovalenko, I.O. Klimenko. Deposition of TiN-based coatings using vacuum arc plasma in increased negative substrate bias voltage // Problems of Atomic Science and Technology. 2019, N 5(123), p. 154-160.

8. A.V. Nikitin, G.D. Tolstolutskaya, V.V. Ruzhytskyi, V.N. Voyevodin, et al. Blister formation on 13Cr2MoNbVB ferritic-martensitic steel exposed to hydrogen plasma // Journal of Nuclear Materials. 2016, v. 478 , p. 26-31.

9. A.I. Zhukov, V.F. Rybalko, G.D. Tolstolutskaya, I.E. Kopanets, L.S. Verkhorobin. Determining the depth profile of deuterium in materials on the yield of nuclear reaction products // Problems of Atomic Science and Technology. 1992, N 1(58), 2(59), p. 133-135. 
10. I.I. Aksenov, A.A. Andreev, V.A. Belous, V.E. Strel'nitskij, V.M. Khoroshikh. Vacuum arc: plasma sources, deposition of coatings, surface modification. Kiev: "Naukova Dumka", 2012.

11. H. Brune. Microscopic view of epitaxial metal growth: nucleation and aggregation // Surface Science Reports. 1998, N 31, v. 4-6, p. 121-229.

12. J.P. Singh, T. Karabacak,

T.-M. Lu, G.-C. Wang. Nanoridge domains in a-phase W films // Surface Science. 2003, v. 538, p. L483-L487.

13. G. Ehrlich, F.G. Hudda. Atomic View of Surface Self-Diffusion: Tungsten on Tungsten // J. Chem. Phys. 1966, v. 44, p. 1039-1049.

14. W. Eckstein. Sputtering Yields / R. Behrisch, W. Eckstein, editors. Sputtering by Particle Bombardment, Topics Appl. Physics. 2007, v. 110, p. 33-187.

15. Li Qiao, Hanwen Zhang, Chuan Xu, Engang Fu, Peng Wang. Erosion and fuel retentions of various reduced-activation ferritic martensitic steel grades exposed to deuterium plasma // Fusion Engineering and Design. 2019, v. 143, p. 188-195.

16. D. Alegre, T. Acsente, A. B. Martin-Rojo, et al. Characterization of tungsten nitride layers and their erosion under plasma exposure in NANO-PSI // Romanian Reports in Physics. 2015, v. 67, N 2, p. 532-546.

17. J. Roth, E. Tsitrone, T. Loarer, et al. Tritium inventory in ITER plasma-facing materials and tritium removal procedures // Plasma Phys. Control Fusion. 2008, v. 50, p. 103001.

18. J. Roth, K. Schmid. Hydrogen in tungsten as plasma-facing material // Phys. Scripta. 2011, v. T145, p. 014031.

19. V.Kh. Alimov, W.M. Shu, J. Roth, S. Lindig, M. Balden, K. Isobe, T. Yamanishi. Temperature dependence of surface topography and deuterium retention in tungsten exposed to low-energy, high-flux D plasma // Journal of Nuclear Materials. 2011, v. 417, N 1-3, p. 572-575.

20. O.V. Ogorodnikova. Fundamental aspects of deuterium retention in tungsten at high flux plasma exposure // Journal of Applied Physics. 2015, v. 118, p. 074902; https://doi.org/10.1063/1.4928407.

21. N. Enomoto, S. Muto, T. Tanabe, et al. Grazingincidence electron microscopy of surface blisters in single- and polycrystalline tungsten formed by $\mathrm{H}^{+}, \mathrm{D}^{+}$ and $\mathrm{He}^{+}$irradiation // Journal of Nuclear Materials. 2009, v. 385, N 3, p. 606-614.

22. L. Gao, W. Jacob, P. Wang, U. von Toussaint, and A. Manhard. Influence of nitrogen pre-implantation on deuterium retention in tungsten // Phys. Scr. 2014, v. T159, p. 014023 (5 p.).

23. L. Gao, W. Jacob, T. Schwarz-Selinger, A. Manhard. Deuterium implantation into tungsten nitride: Negligible diffusion at $300 \mathrm{~K} / /$ Journal of Nuclear Materials. 2014, v. 451, p. 352-355.

\section{ЗАХВАТ ДЕЙТЕРИЯ И РАСПЫЛЕНИЕ ВОЛЬФРАМОВЫХ ПОКРЫТИЙ ПРИ ВОЗДЕЙСТВИИ НИЗКОЭНЕРГЕТИЧЕСКОЙ ДЕЙТЕРИЕВОЙ ПЛАЗМЫ}

\section{Г.Д. Толстолуцкая, А.С. Куприн, А.В. Никитин, И.Е. Копанец, В.Н. Воеводин, И.В. Колодий, Р.Л. Василенко, А.В. Ильченко}

Изучены процессы распыления, модификации поверхности и захвата дейтерия в вольфрамовых покрытиях под воздействием низкоэнергетической $\left(500\right.$ эВ) дейтериевой плазмы с флюенсом $\left(4 \cdot 10^{24} \mathrm{D}^{+} / \mathrm{m}^{2}\right)$. Метод катодно-дугового испарения использован для осаждения W- и WN-покрытий на нержавеющую сталь. Результаты эрозионных исследований показали, что коэффициенты распыления покрытий WN и W составляют $3,1 \cdot 10^{-3}$ и $4,8 \cdot 10^{-3}$ ат./ион соответственно и, как минимум, в два раза больше по сравнению с массивным W, но почти на порядок величины меньше по сравнению с ферритно-мартенситными сталями. Общее количество дейтерия, удерживаемого в $\mathrm{W}$-покрытии, составляло около $5 \cdot 10^{19} \mathrm{D} / \mathrm{m}^{2}$, что примерно на один порядок ниже, чем у WN.

\section{ЗАХОПЛЕННЯ ДЕЙТЕРІЮ І РОЗПИЛЕННЯ ВОЛЬФРАМОВИХ ПОКРИТТІВ ПРИ ДІЇ НИЗЬКОЕНЕРГЕТИЧНОЇ ДЕЙТЕРІЄВОЇ ПЛАЗМИ \\ Г.Д. Толстолуцька, О.С. Купрін, А.В. Нікімін, І.С. Копанець, В.М. Воєводін, І.В. Колодій, Р.Л. Василенко, О.В. Ільченко}

Вивчено процеси розпилення, модифікації поверхні і захоплення дейтерію в вольфрамових покриттях під впливом низькоенергетичної (500 еВ) дейтерієвої плазми 3 флюенсом $\left(4 \cdot 10^{24} \mathrm{D}^{+} / \mathrm{M}^{2}\right)$. Метод катоднодугового випаровування використано для осадження W- i WN-покриттів на нержавіючу сталь. Результати ерозійних досліджень показали, що коефіцієнти розпилення покриттів WN i W складають $3,1 \cdot 10^{-3}$ i $4,8 \cdot 10^{-3}$ ат./іон відповідно i, як мінімум, в два рази більше в порівнянні з масивним W, але майже на порядок величини менше в порівнянні 3 феритно-мартенситними сталями. Загальна кількість дейтерію, утримуваного в $\mathrm{W}$-покритті, становила близько $5 \cdot 10^{19} \mathrm{D} / \mathrm{M}^{2}$, що приблизно на один порядок нижче, ніж у WN. 